When a ring came from the front door bell he answered it to find outside an immaculately dressed young man who looked at his appearance with manifest distaste and asked: "Are you tho caretaker ?" "No", said Piper, "have you brought his dinner?"

Most of Piper's scientific work was in the field of X-rays. When he arrived in Bristol in 1921, McBain was professor of physical chemistry. Piper became interested in some of the soaps on which McBain was working, and made a determination by X-ray diffraction of the structure of their sodium salts. This was the first account of the observations of reflexions from atomic planes with a separation as large as $40 \AA$ units. This work was extended to a study of the hydrocarbons from paraffin wax and to salts of fatty acids; and from 1931 until the Second World War he was closely associated with A. C. Chibnall in experiments on the synthesis and crystal spacing of tho wax constituents of apples, forage grasses and other natural products. In some of this work he was closely associated with Thomas Malkin of the Chemistry Department of the University, who was responsible for tho chemical separations involved in it.

Piper also worked for a period in Bristol with H. W. B. Skinner, who had been appointed, together with L. C. Jackson, at the time of the expansion into the new building in 1927. In Cambridge, Skinner had studied the polarization of light excited in gases by electron impact, and on coming to Bristol he began a series of ambitious experiments, with Piper's support, on the radiations emitted by a single crystal of beryllium under bombardment by electrons. It was just before 'Pyrex' glass had been widely introduced in physical laboratories, and the experiment called for the construction of a very complicated apparatus in a soda-glass envelope, a task of great difficulty at the time and one calling for long and persistent attempts. I can remomber how, in the early hours of one morning in 1929, the twelfth flask in which the apparatus was being assembled fractured while the last of the many side tubes was being inserted and Skinner and Piper immediatoly started on the next. Piper was deeply impressed by the great persistence which Skinnor showed during this collaboration and a long friendship between them resulted from it.

That the early promise of Piper's scientific work was not fully exploited by him was essentially due to his public spirit and his high sonse of duty. Apart from the stress imposod on him by the long years of his War sorvice, and the interruption in his work which it entailed, he always regarded the laboratory as a community and not merely as a research institution, and many of his colleagues were assisted in their own caroers, more than they knew, by the kind reception always extended by him and his wifo at their home.

$$
\text { C. F. POWELL }
$$

\section{Prof. G. J. van Oordt}

The sudden and unexpected death of Prof. G. J. van Oordt, coming so soon after his retirement from the chair of general zoology and endocrinology in the University of Utrecht, has been a great shock to his many friends in Britain. He was a man of very wide interests, and it was his active support of international co-operation in the biological scienens that led him to become so well known in Britain and indeed throughout the world.

During his life the main stroam of his research was concerned with reproduction in the vertebrates. As a postgraduate student his work actually bogan in the field of comparative embryology when, for his doctorate, he described tho carly development of the scaly ant-eater from material collected in Java by Prof. Hubrecht. However, before he even obtained his doctorate he was already intercsted in the physiology of reproduction and in one of his earliest papers he discussed tho internal secretions of the mammalian gonads. Although he continued for some time to study the structure and histology of reproductive systems, particularly in the lower vortebrates, his main interest slowly but steadily shifted towards an experimental and ultimately an endocrinological approach to vertebrate reproduction. Only last autumn, in giving the opening address to the Conference of European Comparative Endocrinologists in London, he reviewed the rosults obtained and the changing opinions held during his own lifetime on the comparative ondocrinology of reproduction in vertebrates. Much of the material included came from his own work or was the work of the many biologists who, throughout the years, had been members of the research group which he founded and encouraged in the Zoology Department in Utrecht.

It will be noted that under van Oordt's direction the Utrecht school of endocrinology has always paid most attention to the problems of the non-mammalian vertebrates. The mammalian and clinical aspects of endocrinology have, of course, been studied extensively throughout the world; it was van Oordt's unique contribution to found what was perhaps the first significant research school in comparative vertebrate endocrinology.

Inextricably mixed with his interest in hormones and breeding cycles was his life-long interest in wild birds, and no appreciation of van Oordt would be complete without mention of this delightful aspect of his character. He was a field ornithologist as a youth, and it was on a birdwatching expedition that he died. It was always one of his greatest pleasures to take his friends, and especially perhaps his friends from overseas, to see the various Dutch nature reserves. On these happy occasions his enthusiasm and his deep feeling for the wild animals and plants of his native country were delightfully obvious.

It was undoubtedly his love for birds and for the open air that led to his becoming such a prominent figure in Nature preservation in the Netherlands. For more than twonty-five years he was a member of the Council of the Netherlands Society for the Protection of Birds and when, following the initial action of private individuals, the Nothorlands Government established State Nature Reserves, van Oordt was appointed to the controlling Advisory Board, and in 1949 he bocamo its chairman. In 1957 he was made president of the highest official committee, the Nature Preservation Council of the Netherlands. Later. still, in 1959, when a Research Institute for Nature Prescrvation was established, its Advisory Committee also sat under his chairmanship. In appreciation of his long years of work for Nature preservation in the Netherlands tho Government appointed him in $1954 \mathrm{a}$ knight of the "Orde van de Nederlandse Leeuw".

Yet another side of van Oordt's character that must be stressed was his love of travel abroad. This took him to endocrinological conferences all over the world, where he acted not only as a scientist but clso as a most able representative of his country. His travels also cnabled him to visit famous nature reserves, for example, in North America and South Africa, and his love of birds even took him as far as Antarctica.

Among those British biologists who do not share his research interests he may perhaps be most widely remembered for his invitation to the Socicty for Experimental Biology, just after the War, to hold a joint meeting with the Dutch biologists in the Utrecht Zoology Department. 'This meeting, which will always be gratefully remembered by those who took part, was so successful that it led to his further happy suggestion that such joint meetings should be held regularly, alternately in Britain and in the Notherlands.

As a person van Oordt's outstanding characteristics were his friendliness, his energy and his restlessness. It was always a stimulus and a delight to be in his company and, above all, to enjoy his great hospitality in his delightful home in Bilthoven. The sympathy of biologists in Britain will go out to his family and also to his many old frionds and colleagues, especially in Utrecht.

\section{W. S. BULLOUGH}

